\title{
PERSEPSI PERKAWINAN USIA DINI DAN PEMBERDAYAAN GENDER (Studi Kasus Desa Pancawati Kecamatan Caringin Kabupaten Bogor)
}

\author{
Ilham Hidayatulloh ${ }^{1}$, Retno Putri ${ }^{2}$, Ter Naotrue ${ }^{3}$, Riswanda ${ }^{4}$, Muhammad Fedryansyah ${ }^{5}$ \\ ${ }^{2}$. Program Pascasarjana Sosiologi, FISIP, Universitas Padjadjaran \\ sukamtoretno@gmail.com
}

\begin{abstract}
ABSTRAK
Persepsi terhadap perkawinan di masyarakat desa memberikan dampak terhadap melonjaknya perkawinan anak usia dini, padahal perempuan berhak mendapatkan kesempatan yang sama dengan laki-laki melalui nilai dan norma dalam menetukan usia perkawinan. Tujuan penelitian untuk menjelaskan pandangan dan persepsi masyarakat dalam perkawinan. Metode penelitian dilakukan dengan kualitatif, hasil penelitian menunjukkan persepsi perkawinan disini dapat dilihat dari empat sudut pandang, yang pertama adalah agama, yang memperbolehkan perkawinan terjadi meskipun usia masih anak-anak selama telah mencapai tanda-tanda kedewasaan, persepsi budaya yang ada di masyarakat memperbolehkan menikah di usia dini, karena stereotip masyarakat terhadap perempuan yang berusia 17 tahun belum menikah dianggap sebagai "perawan tua". Dari sudut pandang ekonomi memberikan pandangan bahwa anak semakin bertambah usianya semakin menjadi beban bagi orang tua, sehingga perkawinan di usia muda menjadi solusi untuk meringankan beban hidup orang tuanya. Sedangkan dari sudut pandang hukum, kelonggaran aturan dalam undang-undang perkawinan memberikan celah bagi mereka yang ingin melakukan perkawinan di usia dini.
\end{abstract}

Kata kunci: persepsi, perkawinan, usia dini, gender, perempuan.

\begin{abstract}
The Perception of marriage in rural society has an impact on the surge in early marriage, even though women are entitled to equal opportunities with men through values and norms in determining the age of marriage. The purpose of the research to explain the views and perceptions of marriage in the society. The research conducted with qualitative methods. the results of the research showed marriage perceptions can be seen from four perspectives, first is religion prespective, which allows marriage even though their ages still a child as long as they have reached signs of maturity. Cultural perceptions that allow marriage at an early age, because the public stereotype of women aged 17 years unmarried is considered as an "spinster". According to the economic view that children are getting older and increasingly becoming an economic burden for parents, so marriage at a young age is a solution to decrease the burden of their parents. In addition, from the legal point of view, the loosening of the rules in the marriage law provides a gap for those who wish to marry at an early age.
\end{abstract}

Keywords: perception, marriage, early age, gender, women.

1,3,4,5. Program Pascasarjana Sosiologi, FISIP, Universitas Padjadjaran 


\section{PENDAHULUAN}

Penelitian tentang perkawinan usia dini (anak) ini dilakukan di Indonesia tepatnya di Desa Pancawati Kecamatan Caringin Kabupaten Bogor. Penelitian ini berfokus pada persepsi perkawinan dalam pemberdayaan gender. Persepsi mengenai perkawinan beragam tergantung dari penilaian mengenai pentingnya perkawinan itu sendiri. Selain membahas tentang persepsi perkawinan, artikel ini juga memfokuskan pada bagaimana perempuan ikut terlibat dalam upaya pemberdayaan. Masih ada kelompok masyarakat yang memiliki persepsi bahwa perempuan tidak perlu mendapatkan pendidikan yang tinggi, karena perempuan memiliki tugas utama sebagai ibu rumah tangga yang mengurus keperluan keluarga mereka. Persepsi keluarga yang seperti itu adalah salah satu faktor para perempuan di desa tersebut tidak melanjutkan sekolah sehingga berakibat pada tingkat pendidikan dan keterampilan rendah.

Telah banyak penelitian-penelitian yang dilakukan mengenai perkawinan anak ini baik di Indonesia ataupun di negara lain namun sangat sedikit yang membahas dari sudut pandang gender dan diskriminasi terhadap gender itu sendiri, penelitian yang dilakukan oleh peneliti terdahulu lebih menitik beratkan kepada kekerasan yang terjadi dalam perkawinan usia anak dan faktor-faktor yang mempengaruhi dari perkawinan usia anak (lihat Segal dan Engelchin (2015), Spezier (2010), Yüksel dan Kaptanoglu (2014)) oleh karena itu artikel mengambil alternatif lain dari dalam memandang permasalahan perkawinan usia anak ini, dengan menfokuskan kepada persepsi perkawinan di dalam keluarga dan konteks pemberdayaan gender dalam perkawinan usia anak ini.

Dalam penelitian ini terdapat dua permasalahan yang mendasar terkait dengan objek penelitian perkawinan usia anak ini, yang pertama adalah bagaimana persepektif keluarga yang anaknya melakukan perkawinan usia dini. Karena mereka pasti memiliki alasan tersendiri dalam melakukan hal tersebut, terlebih lagi cara mereka memandang arti suatu perkawinan pasti berbeda dari keluarga yang tidak melakukan perkawinan berdasarkan usia anak. Kedua adalah bagaimana upaya yang dilakukan pemerintah untuk melakukan pemberdayaan gender, khususnya perempuan agar mereka bisa terlepas dari situasi perkawinan dini. Karena seperti yang kita ketahui bersama bahwa dalam kasus ini perempuan menjadi objek yang tertindas dan terdiskriminasi karena mereka tidak mendapatkan hak-hak mereka terutama hak terhadap pendidikan, kebebasan dalam menentukan pasangan hidup. Padahal hal tersebut sudah diatur dalam Undang-Undang Dasar Republik Indonesia, Pasal 28 B, Ayat 2 dan Pasal 28 C, Ayat 1 yang menyatakan bahwa mereka sebagai anak berhak atas kelangsungan hidup, tumbuh, dan berkembang serta hak atas perlindungan dari kekerasan dan diskriminasi dan juga mereka 
memiliki hak untuk mengembangkan diri melalui pemenuhan kebutuhan dasarnya, hak untuk mendapatkan pendidikan.

Konsep yang digunakan dalam memandang kasus ini adalah kesetaraan gender dan hak-hak perempuan yang dikemukakan oleh Martha C. Nussbaum (1999), yang berpendapat bahwa kesetaraan gender dan hak-hak yang dimiliki oleh perempuan merupakan hal yang terus membentuk pertanyaan-pertanyaan terkait dengan etika dan moral dan tentang cara bagaimana perempuan seharusnya diperlakukan. Akan tetapi, dalam tradisi-tradisi tertentu yang justru mengabadikan ketidaksetaraan bagi perempuan. Seperti dalam konteks kasus ini di mana anak perempuan dinikahkan di usia yang masih sangat muda, sehingga justru perkawinan itu pada akhirnya telah menghambat kemajuan perempuan tersebut dan hal itu merupakan sebuah diskriminasi gender. Martha Nussbaum memberikan sebuah pendekatan untuk keseteraan gender yaitu Capability Approach atau Pendekatan berdasarkan kepada kemampuan. Pendekatan yang dibangun oleh Martha Nussbaum merupakan prespektif yang menganggap bahwa kemampuan universal dapat digunakan untuk mengangkat derajat perempuan ke tempat yang sama dengan laki-laki di dunia. Tentunya pendekatan ini membuka jalan bagi perempuan untuk menjalani kehidupan yang tidak lagi dipengaruhi oleh tradisi yang memungkinkan ketidakadilan bagi para perempuan tersebut.

Pada dasarnya apa yang Nussbaum utarakan mengenai kesetaraan gender bahwa semua manusia baik itu laki-laki atau perempuan harus memiliki kesempatan yang sama untuk memperoleh menjalani kehidupan yang baik. Selain itu, konsep Nussbaum ini mensyaratkan gagasan bahwa perempuan juga memiliki potensi yang sama dengan laki-laki untuk mengeksplor kemampuannya, pendekatan ini penting untuk dilakukan agar perempuan memiliki kesetaraan dengan laki-laki. Dalam arti bahwa seorang wanita memiliki potensi untuk memperluas kemampuannya, maka dia berhak untuk memiliki prospek dalam memenuhi kemampuan tersebut. Pendekatan Kemampuan juga sangat berarti karena menciptakan jalan keluar bagi perempuan untuk dapat mengambil bagian di sektor-sektor yang biasanya didominasi oleh laki-laki seperti halnya dalam sektor pekerjaan di mana laki-laki selalu mendaptakan posisi atau jabatan yang tinggi dibandingkan dengan perempuan.

Dalam pendekatan Nussbaum tentunya perempuan dapat diangkat ke status yang sama dengan laki-laki. Dengan menghadirkan pendekatan ini, bahwa kita harus mendukung kemampuan manusia untuk mencapai potensinya. Yang nantinya akan memunculkan kemampuan kearah positif bagi perempuan dalam mendapatakan hak-haknya dan membuka peluang bagi siapa saja yang ditindas untuk berontak dan membebaskan dari penindasan tersebut.

3 | SOSIOGLLBAAL : Jurnal Pemikiran dan Penelitian Sasiolagi, Vol. 3, №. I, Desember 2018 


\section{METODE PENELITIAN}

Penelitian ini menggunakan desain penelitian studi kasus dengan pendekatan kualitatif, dilakukan di Desa Pancawati Kecamatan Caringin Kabupaten Bogor, dengan melibatkan 5 orang informan yang merupakan pelaku perkawinan dini dan telah memiliki anak. Teknik pengumpulan data menggunakan observasi (pengamatan), wawancara mendalam, dan dokumentasi. Sumber dan jenis data menggunakan kata-kata dan tindakan serta sumber tertulis. Instrumen penelitian adalah peneliti sendiri, dengan menggunakan alat pedoman wawancara.

Prosedur analisis data menggunankan langkah Colaizzi dalam strubert dan Carpenter. Alasan pemilihan metode analisa ini didasarkan pada kesesuaian dengan filosofi Husserl, yaitu suatu penampakan fenomena (informan) realitas itu sendiri yang tampak (Dahlan 2010). Fenomena penelitian ini tentang perkawinan usia dini. Pendekatan fenomenologis menekankan pada pelbagai aspek subjektif dari perilaku manusia supaya dapat memahami tentang bagaimana dan apa makna yang mereka bentuk dari pelbagai peristiwa dalam kehidupan mereka sehari-hari. Dalam penelitian ini, peneliti memiliki latar belakang yang yang sama dengan subjek penelitian dalam hal ini adalah masyarakat Desa Pancawati, yaitu sama-sama memiliki latar belakang sosial budaya Jawa Barat, selaras dengan lokus masyarakat Desa Pancawati, proses berbaur dilakukan selama 2 sampai 3 hari, dalam hal ini alasan pembauran peneliti dengan masyarakat bukan hanya untuk mendapat hasil wawancara yang lebih mendalam, namun juga untuk mencapai kedalaman data terkait perkawinan usia dini, yang dalam hal ini dikaitkan dengan polemik tentang sebuah gejala sosial yang nyata dimasyarakat dan juga polemik tentang gender, yang mana perempuan di Desa Pancawati ini mendapatkan diskriminasi gender yang diakibatkan oleh tradisi perkawinan usia dini di Desa tersebut.

Hal tersebut senada dengan pendekatan Penelitian kebudayaan yang dikemukakan oleh Geertz (1992) tentang kebudayaan simbolik yang menyatakan bahwa kebudayaan juga menjadi suatu sistem konsep yang diwariskan yang terungkap dalam bentuk-bentuk simbolik yang dengannya manusia berkomunikasi, melestarikan, dan memperkembangkan pengetahuan mereka tentang kehidupan dan sikap-sikap terhadap kehidupan. Dan simbol-simbol ini dapat ditangkap dari fenomena yang nyata yang hanya dapat diperoleh melalui pengamatan dan wawancara terhadap informan. Ditambah lagi sebagai peneliti, kita harus memahami betul tentang budaya yang ada di sana. oleh karena itu, sebagian besar penelitian kebudayaan lebih ke arah penelitian lapangan sebagai cara agar bisa mengetahui langsung makna yang ada di dalamnya dan membaur dengan masyarakat agar mendapatkan satu frame yang sama dengan masyarakat yang akan diteliti tersebut. 
Informan yang menjadi subjek penelitian di sini adalah perempuan yang mengalami perkawinan usia dini dalam rentang waktu maksimal sekitar 5 tahun, karena bukan hanya mereka yang baru melakukan perkawinan saja yang perlu diketahui tentang proses mereka menuju jenjang perkawinan, namun peneliti juga merasa perlu untuk melihat kondisi mereka yang sudah melakukan perkawinan tersebut, bagaimana mereka menjalani kehidupan seharihari, bagaimana mereka mengatasi polemik yang ada di rumah tangga mereka. Pemilihan Informan dengan cara tersebut berdasar terhadap argumentasi bahwa perkawinan adalah tahap kehidupan yang perlu diambil dengan pertimbangan yang sangat matang. Terlebih lagi bagi mereka para perempunan ketika menjadi ibu. Ibu yang kepribadiannya sudah matang membuat ia memiliki kualitas tersendiri dalam mengasuh dan mendidik anaknya, serta kematangan psikologis memang tidak selalu sejalan dengan usia biologis. Namun, apabila usianya masih muda memilki kemungkinan besar kematangan psikologisnya pun masih di sekitar usia itu bahkan lebih rendah.

Perkawinan merupakan tahapan kehidupan yang perlu diambil dengan pertimbangan yang sangat matang, baik secara usia maupun psikologis, apalagi kelak mereka para perempuan ini menjadi seorang ibu, yang mana ketika seorang ibu sudah memiliki kematangan dapat memberikan mereka kualitas tersendiri dalam mengasuh dan mendidik anaknya. Memang kematangan psikologis tidak selalu selaras dengan bertambah usia biologis, namun apabila dalam usia muda, kemungkinan besar kematangan psikologisnya pun masih berada di lingkup usia biologisnya atau bahkan lebih rendah dari usia biologisnya tersebut. Karena dalam prosesnya apalagi kelak mereka akan menjadi seorang ibu, gejala hamil, melahirkan, menyusui, merawat dan mengasuh anak bukanlah kondisi yang selalu nyaman. Seringkali dihinggapi rasa tidak nyaman, sakit, tidak enak, pengorbanan fisik seperti kekurangan waktu tidur, sampai pengorbanan mental di mana harus mengutamakan kebutuhan bayi kecil di atas kepentingan diri sendiri, maka di sinilah dituntut kematangan secara psikologis. Bagi perempuanperempuan muda yang hidup di zaman ini. Perkawinan usia di usia muda untuk generasigenerasi yang lalu mungkin tidak sekrusial saat ini, zaman lalu perkawinan usia dini dianggap wajar dan memang sering dilakukan. Namun dewasa ini, perkawinan usia dini sudah dianggap kuno dan tidak sesuai dengan zaman sekarang, karena di dalam perkawinan usia dini ini selalu ada gender perempuan yang terdiskriminasi hak-haknya. 


\section{PEMBAHASAN}

Perkawinan merupakan suatu hubungan yang sakral antara perempuan dan laki-laki, sah secara agama maupun hukum, yang nantinya dari perkawinan tersebut akan menciptakan keseimbangan dengan terpenuhinya secara biologis, psikologis maupun sosial. Perkawinan tersebut sudah terjadi diseluruh wilayah yang ada di Indonesia ini baik dari wilayah perkotaan maupun pedesaan. Akan tetapi perkawinan saat ini menjadi suatu permasalahan yang umum karena usia perkawinan yang sangat muda baik perempuan dan laki-laki menjadi hal yang kurang mendukung, sebab kematangan mental dan stabilitas emosi sesorang belum terkontrol secara seimbang.

\section{Prespektif Keluarga dalam Perkawinan Usia Dini}

Perkawinan usia dini saat ini bisa dilihat dari pelbagai wilayah apa lagi pedesaan. Masyarakat pedesaan cenderung akan melakukan perkawinan dini. Hal ini dikarenakan masyarakat pedesaan sebagian besar masih memegang paham lama yang koserpatif dan masih pada prinsip yang merujuk pada budaya, yang sudah tertanam pada masyarakat desa dalam hubungan perkawinan. Hal tersebut yang mendukung masyarakat untuk tetap melakukan perkawinan usia dini yang sampai saat ini terjadi dan mudah ditemukan di wilayah pedesaan.

Wilayah pedesaan sebagai faktor yang paling dominan bagi masyarakat untuk menikahkan anak-anaknya di usia dini. Sebab, lingkunganlah yang membiasakan perkawinan usia dini, sehingga menjadi budaya yang secara terus menerus dilakukan dan menganggap perkawinan usia dini sebagi titik awal untuk terlepas dari beban moril dan ekonomi keluarganya. Untuk membuat nilai tersendiri agar terhindar dari pembicaraan masyarakat yang biasa disebut perawan tua. Menurut masyarakat setempat jika tidak menikahkan anak-anaknya terlepas dari umur 18 tahun akan menimbulkan insiden tersendiri bagi keluarganya dan anaknya.

Anggapan ini menjadi suatu momok menakutkan bagi kebanyakan keluarga tradisional masyarakat. Citra dan pandangan masyarakat menjadi suatu jalan hidup yang harus dijalankan maupun dihindari. Pergaulan hiduplah dan interkasi tersebut menjadikan perkawinan dini menjadi legitimasi yang bersifat lumrah dari masyarkat. Keterpaksaan dalam mejalankan realitas perkawinan dini akibat dari stigma yang berkembang dan akan berkembang di masyarkat.

Oleh karena itu, perkawinan hanya diihat sebagai kebutuhan biologis semata tidak melihat dari aspek dampak secara sosial. Akhirnya yang terjadi kemudian, banyak mayarakat Indoesia yang melakukan perkawinan dini dan tidak siap dengan kehidupan pasca menikah, akibatnya 
perceraian di usia muda banyak terjadi. Hal tersebut disebabkan karena ketidak matangan secar mental.

Namun, dalam realitas yang terjadi saat ini perkawinan usia dini sudah menjadi hubungan perkawinan yang menjadi nomor satu di Indonesia, antara manusia saat ini. Pembentukan secara sosial ini atas dasar dari kehidupan di lingkungan masyarakat yang mengkukuhkan bahwa perkawinan usia dini hal yang layak bagi anak-anaknya, karena orang tua memberikan dorongan untuk melakukan perkawinan dini. Hal ini seperti layaknya perkawinan yang sewajarnya dilakukan walapun secara medis usia dini sangat belum matang dalam reproduksi. Akan tetapi, hal tersebut tidak semata-mata difikirkan karena menurut masyarakat jika keduanya saling mendukung dan siap menikah usia dini tentunya tetap dijalankan. Hal itu terjadi karena minimnya pengetahuan masyarakat terhadap perkawinan dini yang menjadi dasar untuk terbentuknya perkawinan dibawah umur.

Dibuktikan dalam data perkawinan dini yang dikeluarkan oleh BPS dan UNICEF bahwa di Indonesia dengan jumlah 340.000/tahun perempuan yang menikah dini, prevalensinya akan terus meningkat, sehingga dalam persentase laporan UNICEF bahwa perkawinan usia dini sebanyak 20\% pada tahun 2012. Yang dimana plan internasional menunjukkan bahwa adanya pemalsuan umur anak oleh oknum pejabat daerah yang mengubah usia anak dalam pencatatan perkawinan. Sebab dilihat dari tingkat perkawinan anak usia dini adanya faktor yang mendorong, untuk memberikan kesempatan terhadap masyarakat dalam melakukan tindakan yang mestinya tidak harus dilakukan dalam anak dibawah umur.

Data yang dikeluarkan oleh BPS dan UNICEF, melihat bahwa Indonesia sebagai tingkat perkawinan anak usia dini yang pada tahunnya memiliki peningkatan, sebab di Negara Indonesia semakin masyarakat berada di wilayah pedesaan semakin banyak masyarakat ataupun orang tua yang menikahkan anaknya dibawah umur. Data yang menunjukan sebagian besar wilayah pedesaan di Indonesia dengan persentase 25\% melakukan perkawinan dibawah umur dibandingan dengan masyarakat kota dengan persentase 19\%. Dalam data tersebut menunjukan bahwa kurangnya kesejahteraan pada masyarakat desa yang secara material dan non material tidak mendukung untuk menjadi lebih berkembang dan kehidupan lebih baik.

Walaupun di Indonesia sudah menerapkan untuk wajib menyelesaikan pendidikan dengan waktu yang sudah ditentukan sebagai titik awal perubahan agar mencegah terjadinya perkawinan dini. Akan tetapi penerapan pendidikan selama 12 tahun tidak dirisaukan oleh masyarakat dalam arti masyarakat desa hanya menomor duakan pendidikan dalam kepentinganya. Hal itu yang menjadikan pemikiran masyarakat tidak maju dalam melakukan 
perubahan kehidupan sosial masyarakat desa. Sistem yang tertanam dalam lingkungan masyarakat tidak akan dirubah jika lingkungan sekitar tidak memiliki keinginan untuk memberikan hak pada anak dalam pendidikan yang semata-mata meninggalkan perkawinan dibawah umur.

Tentunya masyarakat desa jika dilihat sosiologis, menikahkan anaknya diusia dini memiliki alasan tersendiri. Di mana alasan tersebut sebagai batasan masyarakat untuk meringankan beban ekonomi keluarganya agar anaknya terlepas dari tanggung jawab orang tuanya. Sudah menjadi hal yang nampak bahwa ekonomi masyarakat desa pada tingkat menengah ke bawah, yang menjadi faktor pendorong untuk melakukan tindakan tersebut bahwa menikahkan anaknya di usia dini sebagai jalan keluar untuk kehidupan orang tua maupun anaknya. Pada dasarmya masyarakat desa tidak ingin berada pada posisi yang membuat anaknya untuk menerima perkawinan dini namun keadaan masyarakat desa yang rendah untuk mendapatakan perubahan yang selayaknya masyarakat kota dapatkan.

Untuk melihat perkawinan dini dikalangan masyarakat desa dapat dibuktikan dengan data yang ditujukan pada wilayah Provinsi Jawa Barat yaitu 30,5 \% bahwasannya para pejabat daerah sudah menerapakan untuk tidak melakukan perkawinan anak di usia dini. Namun hal tersebut hanya sebagai informasi yang tidak perlu diterapkan pada masyarakat pedesaan saat ini. Karena pada tingkat Kecamatan tiap daerah pedesaan memiliki nilai persentase yang berbeda-beda seperti Curug Kembar 43\%, Caringin 34\% dan Ciemas 31\%. Dengan nilai yang menunjukan bahwa paling tinggi perkawinan anak usia dini yaitu Curung Kembar dan untuk pada tingkat menengah terjadi di Kecamatan Caringin. Hal ini lah yang akan diangkat dalam realitas masyarakat Kecamatan Caringin bahwa perubahan untuk menjadi menurun tingkat perkawinan anak usia dini tidak pernah terjadi. Sehingga akan menjadi pembahasan dalam artikel ini mengapa Kecamatan Caringin tidak menunjukan perubahan tetap berada pada kategori menengah.

Desa Pancawati sebagai desa yang menjadi simbol masyarakat desa lainnya dalam tingkat persentase perkawinan usia dini yang sudah mendarah daging pada kehidupan lingkungan masyarakat. Hal ini terjadi karena masyarakat Desa Pancawati sudah kental akan nilai budaya yang berpengaruh pada tingkat kehidupan dan kesejahteraan perempuan. Bahwa perempuan Desa Pancawati sebagian besar melakukan sistem perkawinan dibawah umur. Di mana dengan hasil wawancara oleh 5 (lima) respon menunjukkan perempuan-perempuan desa tersebut walaupun memiliki tingkat ekonomi yang mapan, menengah dan kebawah diakhir pendidikan yang mereka dapatkan harus berujung pada perkawinan usia dini dan mengurus keluarga dengan usia yang masih muda. 
Tentunya akan ada respon tindakan dan interaksi masyarakat dalam lingkungan yang saling berpengaruh sehingga perkawinan anak di usia dini tidak akan lepas dalam masyarakat Desa Pancawati. Dengan hal itu, Desa Pancawati menjadi masyarakat yang secara ekonomi memiliki tingkat pendapatan yang seimbang dalam arti terdapat masyarakat dengan pelbagai tingkat ekonomi, mulai dari level atas, menengah dan bawah. Hal tersebut menunjukkan secara sumber daya manusia beserta sumber daya alam memiliki potensi yang mampu membuat masyarakat menjadi lebih berkembang dan maju.

Namun, bagi masyarakat setempat untuk merubah pola hidup dan pemikiran masyarakat berubah suatu hal yang kurang mendukung, karena dari sisi pemerintahan daerah setempat kurang adanya partisipasi pada masyarakat untuk memberikan pemikiran yang lebih maju dalam kehidupannya. Seperti halnya tidak adanya sosialisasi dan penyuluhan kepada masyarakat setempat tentang dampak dari perkawinan usia dini secara mendetail dan kurangnya dalam memberikan pengetahuan didunia pendidikan. Sehingga akan berpengaruh terhadap pemikiran masyarakat bahwa respon masyarakat pada saat itu menunjukkan untuk tingkat pendidikan hal yang tidak wajib dilakukan walaupun dari sisi ekonomi sangat mendukung, namun keinginan untuk berpendidikan sangat rendah.

Hal ini lah yang akan mendukung perkawinan di usia dini menjadi hal yang diharuskan di Desa Pancawati. Dilihat dari lingkungan serta tanggapan masyarakat, di mana masyarakat menikahkan anaknya diusia dini memiliki alasan untuk mendorong anaknya menikah. Seperti hal tradisi budaya masyarakat desa yang masih kolot yang memperkuat bahwa menikahkan anaknya diusia dini menjadi hal yang wajar dilakukan pada lingkungan masyarakat Desa Pancawati untuk menjaga nama baik anak perempuan tersebut agar terlepas dari istilah perawan tua. Yang didominasikan jika perempuan sudah balig ataupun memiliki kesiapan diri belum menikah itu akan membuat nama perempuan dan keluarganya menjadi buruk dan perbincangan lingkungan masyarakat. Dan kebiasaan lainnya yang disampaikan informan adalah pantangan untuk menolak lamaran yang diajukan oleh pihak laki-laki terhadap perempuan yang ingin dinikahinya, karena ketika lamaran tersebut ditolak maka akan menjadi pergunjingan diantara tetangga mereka, sehingga meskipun anak-anaknya masih dibawah umur untuk menikah namun ketika ada lamaran yang datang kepada pihak keluarga, maka harus disetujui dan segera menikahkan anaknya dengan pelamar tersebut.

Tidak hanya itu saja yang mendominan masyarakat desa dalam menikahkan anaknya diusia dini, bisa dilihat dari ekonomi keluarga bahwasanya pihak dari keluarga perempuan ingin melepas anaknya agar beban ekonomi keluarga berkurang, yang nantinya akan menjadi tanggung jawab suaminya. Dan juga keluarga memiliki harapan yang nantinya dapat membantu 9 | SUSIOGLLBBAL : Jurnal Pemikiran dan Penelitian Sasiologi, Val. 3., №. I, Desember 20I8 
beban ekonomi keluarga dari penghasilan suaminya. Selanjutnya timbul kekhawatiran orang tua kepada perilaku anak saat ini, karena untuk wilayah Desa Pancawati lingkungan menjadi wadah bagi anak-anak dalam melakukan hubungan seks diluar nikah, hal itu terjadi karena kurangnya fasilitas penerang jalan sehingga jalan Desa Pancawati menjadi gelap dan cenderung sepi sehingga tempat-tempat tersebut menjadi tempat untuk melakukan perjinahan atau hubungan seks. Karena secara letak geografis Desa Pancawati jauh dari akses utama, sehingga masyarakat desa jauh dari lingkungan keramaian dan tidak adanya masyarakat lain untuk melewati akses jalan Desa Pancawati saat malam hari.

Dari pelbagai alasan yang dikemukakan oleh keluarga yang menikahkan anaknya di usia dini merupakan suatu hal yang tepat, di sisi lain pemerintah desa dalam sangat menentang keras tentang terjadinya perkawinan dini tersebut. Pemerintah desa berargumen bahwa seiring perkembangan zaman, pendidikan menjadi sangat penting bagi warga masyarakat. Persayaratan untuk bekerja yang rata-rata harus melaksanakan pendidikan hingga minimal SMA, sangat disayangkan apabila para anak-anak khususnya perempuan ini menikah secara dini. Karena ketika melakukan perkawinan, mereka harus dituntut dewasa dalam pelbagai hal dan bertanggung jawab atas yang terjadi di dalam keluarganya. Setelah menikah, mereka dituntut melakukan semuanya sendiri mulai dari mengurus keperluan rumah tangga, mengurus suami, dan apalagi mereka apabila sudah melahirkan tanggung jawab yang diemban pun bertambah. Dengan ketidakdewasaan yang masih tertanam dijiwa anak-anak perempuan tersebut, biasanya ketika mereka melihat anaknya nangis, maka mereka pun ikut menangis semua karena tidak tahu bagimana cara mengatasi hal tersebut.

Apabila praktek perkawinan dini ini dibiarkan terus menerus, pemerintah desa beranggapan bahwa angka perkawinan di desanya akan terus menurun dan mencapai rata-rata menikah di angka 15 tahun, dan hal tersebut tentu belum mencapai batasan umur yang sesuai dengan Undang-Undang perkawinan. Dalam UU No. 1/1974 tentang perkawinan disyaratkan bahwa usia minimum perempuan menikah adalah 16 tahun sementara laki-laki 19 tahun dengan izin orang tua. Namun terkadang hal tersebut seolah-olah diabaikan oleh keluarga yang menikah dini tersebut. Apabila anak-anak mereka tidak dapat dinikahkan secara sah oleh hukum, mereka lebih memilih menikahkan anaknya secara siri atau perkawinan yang sah secara agama namun tidak diakui oleh hukum, dan apabila telah mencapai usia yang ditetapkan oleh pemerintah mereka baru melaporkan perkawinan tersebut kepada Kantor Urusan Agama.

Namun hal tersebut dibenarkan oleh pemuka agama Islam di desa tersebut, mereka beranggapan bahwa perkawinan dapat terjadi apabila mereka sudah mencapai batas-batas yang ditetapkan oleh agama, dan apabila mereka telah saling suka satu sama lain, maka segera SLSIOGLLBAL : Jurnal Pemikiran dan Penelitian Sosiologi, Vol. 3, No.I, Desember 20I8 | I0 
dinikahkan demi mencegah perbuatan zina dan menikah merupakan salah satu cara untuk melestarikan keturunan. Hal tersebut menjadi kesulitan tersendiri bagi pemerintah untuk mencegah dan melarang terjadinya perkawinan di usia dini.

Dari segala aspek yang menjadi alasan orang tua untuk menikahkan anaknya di usia dini, tentunya dilatarbelakangi oleh pola pikir dari orang tua yang sangat minim, mereka hanya mencari jalan keluar yang cepat dan sesaat tanpa berpikir panjang terhadap kehidupan anaknya, bahkan dengan melakukan hal yang melanggar hukum pun mereka tempuh. Hal itu lah yang menjadikan pola asuh dari orang tua seperti ini tidak dibenarkan secara moril. Karena dalam pengasuhan anak tersebut tidak mencerminkan orang tua yang ingin menjadikan anaknya lebih maju dan berkembang dan menghancurkan kehidupan masa depan anaknya dengan hanya memberikan pendidikan anaknya dibatas minimum agar lebih cepat dinikahkan dengan pilihan orang tua maupun dari pilihan anaknya tersebut. Belum lagi dengan adanya sistem perjodohan dalam masyar untuk yang saling menjodohkan untuk kebaikan anakanaknya. Karena pemikiran orang tua dengan menjodohkan anaknya dengan orang atau keluarga yang dikenalnya, maka akan menjadi lebih baik untuk kehidupan anaknya. Namun dewasa ini sistem perjodohan di Desa Pancawati cenderung mengalami penurunan, sebab bagi anak masyarakat Desa Pancawati lebih banyak untuk menentukan pilihannya sendiri kejenjang perkawinan ketimbang menerima calon yang dijodohkan oleh orang tuanya.

Persetujuan dan kesiapan anak untuk melakukan perkawinan usia dini tentunya karena minimnya pengetahuan dalam perkawinan usia dini. Bahwa masyarakat Desa Pancawati untuk tingkat pendidikan yang rendah, sehingga masyarakat desa hanya memiliki pengetahuan berdasarkan yang mereka lihat apa dilakukan orang lain dalam lingkungannya. Seakan pendidikan bagi masyarakat Desa Pancawati tidak dianggap begitu penting, seperti yang dialami oleh salah satu informan yang memiliki tingkat ekonomi baik dan mapan, orangtuanya lebih menunggu calon yang akan melamar anaknya untuk menikah daripada memilih menyekolahkan anaknya padahal dalam hal ekonomi keluarganya lebih mapan dari yang lain di daerah tersebut. Hal tersebut pun terjadi di kalangan ekonomi yang rendah, mereka lebih mendorong untuk melepas anaknya dan menikahkan anaknya dalam usia dini agar terlepas dari beban ekonomi yang membelenggu keluarga mereka. Dengan demikian, hal-hal yang memperkuat perkawinan anak usia dini di Desa Pancawati tidak hanya dorongan tradisi budaya saja, melainkan tingkat pengetahuan orang tua yang rendah tentang perkawinan ditambah lagi dengan benturan tradisi yang ada dan sudah mengakar dimasyarakat menjadikan perkawinan di usia dini selalu terjadi dalam masyarakat. 
Perkawinan sesungguhnya memang merupakan bagian dari hak individu yang tidak menimbulkan kerugian bagi kalangan lain, namun ketika perkawinan ini terjadi pada usia anak pelbagai masalah pun muncul, salah satunya adalah hak anak untuk mendapatkan pendidikan. Terjadinya perkawinan usia dini pada usia anak menyebabkan mereka kehilangan hak dan semangat untuk mendapatkan dan memperoleh pendidikan, karena tanggung jawab mereka bukan lagi untuk belajar namun setelah menikah mereka berfokus untuk membangun rumah tangga, ditambah lagi biasanya sekolah-sekolah yang ada enggan untuk menerima siswa yang sudah menikah di usia dini ini. Selain masalah pendidikan, kesehatan juga masalah besar dari perkawinan dini ini. Menurut WHO, Anak perempuan usia 10-14 tahun memiliki risiko lima kali lebih besar untuk meninggal dalam kasus kehamilan dan persalinan daripada perempuan usia 20-24 tahun, dan secara global kematian yang disebabkan oleh kehamilan merupakan penyebab utama kematian anak perempuan usia 15-19 tahun. Selain masalah pendidikan dan kesehatan, ada juga masalah psikologis. Pelbagai kajian menunjukkan bahwa anak perempuan yang menikah pada usia dini memiliki risiko tinggi untuk mengalami kecemasan, depresi, atau memiliki pikiran untuk bunuh diri, sebagian dapat disebabkan mereka tidak memiliki status, kekuasaan, dukungan, dan kontrol atas kehidupan mereka sendiri. Selain itu mereka juga kurang mampu untuk menegosiasikan hubungan seks aman, sehingga meningkatkan kerentanan mereka terhadap infeksi menular seksual seperti HIV. Kajian lain juga menunjukkan bahwa pengantin anak memiliki peluang lebih besar untuk mengalami kekerasan fisik, seksual, psikologis, dan emosional, serta isolasi sosial, yang merupakan akibat dari kurangnya status dan kekuasaan mereka di dalam rumah tangga mereka.

\section{Upaya Pemerintah dalam Melakukan Perkawinan Usia Dini}

Pemerintah indonesia sudah berupaya untuk menekan angka perkawinan usia dini ini, salah satunya melalui Kementrian Pendidikan dan Kebudayaan (kemendikbud) pada tahun 2015 memperbaharui program wajib belajar 9 tahun menjadi program wajib belajar 12 tahun. Program wajib belajar ini merupakan pendidikan penting yang harus diikuti oleh setiap warga negara Indonesia agar mendapatkan pendidikan yang berkualitas untuk masa depannya. Program wajib belajar ini memiliki fungsi untuk mengupayakan peningkatan kualitas dan mutu pendidikan bagi warga negara Indonesia dan program pendidikan ini juga memberikan suatu pendidikan minimal bagi mereka untuk dapat hidup mandiri dan bersaing ditengah masyarakat. Selain itu juga pemerintah menggalakan tersebarnya Kartu Indonesia Pintar (KIP) agar anakanak yang kurang mampu dapat melanjutkan pendidikan mereka sampai ke jenjang Sekolah Menengah Atas (SMA) atau Sekolah Menengah Kejuruan (SMK) tanpa biaya sehingga mereka 
yang memiliki tingkat ekonomi yang rendah dapat melanjutkan pendidikannya minimal program wajib belajar 12 tahun ini terpenuhi.

Selain Itu juga Pemerintahan Indonesia juga melakukan kampanye bahaya perkawinan usia dini bagi kesehatan perempuan, karena seperti yang dipaparkan di atas perkawinan dini memiliki risiko tinggi terhadap kesehatan khususnya perempuan. Salah satu di antara program pemerintah itu adalah program yang gagas BKKBN terkait tentang kampung KB. Kampung KB memiliki pelbagai program yang bisa membantu mencegah perkawinan dini. Salah satunya penyuluhan dari pelbagai dinas seperti dinas pendidikan dan dinas kesehatan tentang dampak negatif perkawinan dini. Namun hal itu belum cukup mampu mendorong anak-anak tersebut untuk terhindar dari perkawinan, hal itu karena keluarga dari anak tersebut juga menentukan dan menjadi faktor penentu utama dalam hal perkawinan usia anak ini.

Pada dasarnya perkawinan memiliki pelbagai macam persepsi tergantung pada sudut pandang mana orang menilai bagaimana suatu perkawinan ini dianggap penting. Dalam sisi agama khususnya dalam agama Islam perkawinan adalah suatu hal yang wajib hukumnya dan apabila sudah mencapai usia baligh, usia baligh ini adalah umur bagi seorang laki-laki yang belum mengeluarkan sperma (mani) dan perempuan yang belum mengeluarkan darah haid. Namun syariat atau hukum agama Islam sendiri tidak memberikan penjelasan terkait batasan usia untuk melakukan perkawinan baik itu batas minimal ataupun maksimal. Syariat agama islam hanya menjelaskan tentang menciptakan keluarga yang sakinah serta memperoleh keturunan dengan tujuan dari perkawinan itu sendiri adalah menjaga keturunan. Tujuan menjaga keturunan tersebut juga dipengaruhi usia calon mempelai yang telah sempurna akalnya dan siap melakukan proses reproduksi. Menurut syariat Islam, usia kelayakan perkawinan adalah usia kecakapan berbuat dan menerima hak yaitu mencapai akil baligh. Dalam Islam tidak menentukan batas usia namun mengatur apabila seseorang sudah mencapai usia baligh baik itu laki-laki atau perempuan, dianggap siap untuk menerima pembebanan yang hukum Islam. Sehingga menurut syariat Islam, Perkawinan dini pada dasarnya dianggap sah sepanjang telah memenuhi syarat-syarat dan rukun nikah yang ditetapkan dalam islam, yang di dalamnya tidak ada ketetapan mengatur usia seseorang untuk menikah. Sehingga hal tersebut memberikan dorongan pada keluarga untuk sesegera mungkin melakukan perkawinan terhadap anak perempuannya meskipun anak perempuannya tersebut masih dalam usia anak-anak yang masih mempunyai hak untuk bersekolah dan mendapat pendidikan yang layak. Seperti yang dipaparkan di atas bahwa bagi masyarakat Desa Pancawati pun demikian, bahwa ketika mereka sudah memasuki usia baligh mereka sudah siap untuk dikawinkan. 
Dilihat dari sudut pandang budaya, perkawinan usia dini ini merupakan budaya yang sudah turun temurun dilakukan di Indonesia. Budaya merupakan salah satu faktor utama yang mengakibatkan suatu kebiasaan tersebut dapat bertahan lama, budaya perkawinan dini umumnya terjadi pelosok-pelosok daerah di Indonesia khususnya di daerah pedesaan. Stigma di masyarakat-masyarakat desa tersebut umumnya bahwa anak perempuan yang berusia 17 tahun maka akan dianggap sebagai "perawan tua" sehingga faktor stigma di masyarakat inilah yang membuat keluarga menjadi takut dan ingin segera menikahkan anak-anaknya. Faktor budaya dan agama saling menguatkan argumen satu sama lain. Di sisi lain, agama ikut menganjurkan perkawinan usia dini apabila anak tersebut sudah mengalami hal-hal yang membuat dia dapat dikatakan mencapai akil baligh, di sisi lain juga budaya ikut memperkuat argumen dari interpretasi agama ini, yaitu stigma perawan tua di usia 17 tahun. Sehingga mereka mampu menjadi faktor utama dalam perkawinan anak usia dini ini.

Selain itu juga sudut pandang ekonomi juga ikut mempengaruhi dari perkawinan dini ini, mereka yang mengawinkan anaknya di usia dini mengaggap bahwa anak merupakan beban bagi ekonomi keluarga mereka ketika mereka sudah beranjak dewasa, kewajiban keluarga untuk menyekolahkan mereka, membuat beban ekonomi semakin bertambah, sehingga jalan satu-satunya adalah dengan mengawinkan anak mereka dengan pria yang sudah memiliki kemapanan ekonomi sehingga beban keluarga menjadi berkurang. Karena anaknya sudah menjadi tanggung jawab laki-laki yang menikahinya.

Apabila dilihat dari sudut pandang lain seperti hukum, ada Undang-Undang yang mengatur perkawinan yaitu Undang-Undang Nomor 1 Tahun 1974 pada Pasal 7 Ayat (1) yang berbunyi "Perkawinan hanya diizinkan bila pihak pria mencapai umur 19 (sembilan belas) tahun dan pihak wanita sudah mencapai usia 16 (enam belas) tahun." Pasal 7 Ayat (2) berbunyi, "Dalam hal penyimpangan dalam ayat (1) pasal ini dapat minta dispensasi kepada Pengadilan atau pejabat lain yang diminta oleh kedua orang tua pihak pria atau pihak wanita." Aturan yang dibuat dalam Undang-Undang tersebut juga menjadi bagian dari banyaknya perkawinan anak khususnya anak perempuan dalam hal ini mengalami perampasan terhadap hak-hak mereka untuk tumbuh berkembang seperti yang tercantum pada Undang-Undang Dasar 1945 pasal 28 B Ayat (2) yang berbunyi "Hak anak untuk kelangsungan hidup, tumbuh, dan berkembang serta hak atas perlindungan dari kekerasan dan diskriminasi." Dan juga Pasal 28 C ayat (1) yang menyatakan bahwa "Hak untuk mengembangkan diri melalui pemenuhan kebutuhan dasarnya, hak untuk mendapatkan pendidikan dan memperoleh manfaat dari ilmu pengetahuan dan teknologi, seni, dan budaya." 
Persepsi yang berbeda-beda dalam maknai perkawinan seperti yang disampaikan sebelumnya memberikan pengaruh besar dalam membelenggu hak-hak dari anak itu sendiri khususnya anak perempuan untuk mencapai kesetaraan antar gender. Seperti yang dikemukakan oleh Martha C. Nussbaum bahwa ketidaksetaraan gender merupakan akibat dari tradisi-tradisi yang diabadikan yang mendiskriminasi gender khususnya perempuan, apabila dilihat dari konteks persepsi-persepsi yang dipaparkan sebelumnya, faktor persepsi agama dan budaya menjadi faktor utama membuat perempuan seolah-olah dibuat tidak berdaya dan tidak mampu memperjuangkan hak-hak mereka untuk mendapatkan kesempatan yang sama seperti yang didapatkan oleh laki-laki. Tidak adanya aturan dalam batasan usia untuk melakukan perkawinan menurut agama dalam hal ini Islam memberikan peluang untuk melanggengkan perkawinan usia dini tersebut untuk terus terjadi, ditambah dengan faktor dari budaya yang sudah menjadi tradisi turun temurun untuk menikahkan anaknya di usia muda dan stigma "perawan tua" terhadap perempuan muda yang belum menikah di usia muda menjadi salah satu alasan yang mendorong terjadinya perkawinan anak usia dini.

Ditambah lagi dengan faktor-faktor lain seperti ekonomi yang menjadi alasan bagi sebuah keluarga untuk mengawinkan anak perempuannya pada usia dini yang memungkinkan mereka terbebas dari beban ekonomi anak-anaknya tersebut. Dan juga hukum di Indonesia yang tidak mempunyai ketegasan dan tidak langsung memperbolehkan praktik perkawinan usia dini untuk tetap ada. Faktor-faktor tersebut yang merupakan penghambat bagi perkembangan pemberdayaan perempuan di Indonesia, seperti yang dikemukakan oleh Nussbaum, pada dasarnya pendekatannya ini menginginkan setiap gender memiliki kesetaraan secara universal. Namun dengan aturan agama yang mengekang perempuan untuk mendapatkan hak-haknya, budaya yang masih berorientasi pada satu gender yaitu laki-laki untuk berkembang. Dan hukum yang tidak adil bagi perempuan membuat perkembangan untuk pemberdayaan gender terhadap perempuan terhambat.

\section{SIMPULAN}

Pada akhirnya permasalahan mengenai perkawinan usia dini ini menjadi permasalahan yang harus diselesaikan secara bersama. Bukan hanya menjadi tanggung jawab pemerintah, tetapi masyarakat juga harus saling mengingatkan satu sama lain, kemauan untuk merubah cara pandang terhadap perkawinan juga harus mulai dilaksanakan secepat mungkin, karena keberagaman sudut pandang ini lah yang memberikan persepsi yang berbeda-beda terkait perkawinan sehingga timbul permasalahan tersebut.

Pemerintah juga diharapkan mampu mempertegas aturannya dengan cara mengubah undangundang perkawinan yang berkeadilan, khususnya adil bagi mereka yang masih berusia anak-

15 | SLSIOGLOBAL : Jurnal Pemikiran dan Penelitian Sasiologi, Vol. 3, No. I, Desember 2018 
anak agar tidak ada paksaan untuk menikah ketika mereka sudah menjadi dewasa. Dengan memberikan peraturan yang ketat dalam syarat-syarat untuk melakukan perkawinan diharapkan mampu menekan angka perkawinan dini.

\section{DAFTAR PUSTAKA}

Aminah, Andi Nur. Perlu Ubah Tradisi Agar Tak Terjadi Perkawinan Remaja. http://nasional.republika.co.id/berita/nasional/umum/13/04/30/mm1rbp-plusminusdoktrin-budaya-pada\%20perkawinan\%20-dini. Diakses Tanggal 14 April 2018.

Badan Pusat Statistik. Perkawinan Usia Anak di Indonesia 2013 dan 2015 Edisi Revisi. https://www.bps.go.id/publication/2017/12/25/b8eb6232361b9d8d990282ed/perkaw inan-usia-anak-di-indonesia-2013-dan-2015-edisi-revisi.html. Diakses Tanggal 12 April 2018

Evenhuis and Burn. Just Married, Just a Child, p. 25

Geertz, Clifford. 1992. Tafsir Kebudayaan, Yogyakarta: Kanisius Press.

Jain and Kurz. New Insights on Preventing Child Marriage, p. 8; ICRW

Kardi, Dika Kania. Kontroversi Perkawinan dini dan Polemik batas Usia Perkawinan. https://www.cnnindonesia.com/nasional/20180417110228-12-291347/kontroversiperkawinan-dini-dan-polemik-batas-usia-perkawinan. Diakses tanggal 12 April 2018

Mediani, Mesha. Perkawinan Dini dan Persoalan Hak Anak yang Tak Terlindungi. https://www.cnnindonesia.com/nasional/20180418100224-20-291626/perkawinandini-dan-persoalan-hak-anak-yang-tak-terlindungi. Diakses Tanggal 19 April 2018

Nussbaum MC. 1999. Seks and social justice. Oxford University Press, New York

Raj, A. 2010. When the mother is a child: The impact of child marriage on the health and buman rights of girls. Boston. Archives of disease in childhood. 95, (11), p. 931.

Romadoni, Ahmad. Unicef Soroti Perkawinan Dini di Indonesia. https://www.liputan6.com/news/read/2870119/unicef-soroti-perkawinan-dini-diindonesia. Diakses Tanggal 19 April 2018.

Rostanti, Qommarria. Faktor Budaya Jadi Penyebab Perkaninan Dini di Pelosok. http://nasional.republika.co.id/berita/nasional/umum/17/07/24/otl6v2425-faktorbudaya-jadi-penyebab-perkawinan-dini-di-pelosok. Diakses Tanggal 12 April 2018.

Sasongko, Agung. Begini Islam Memandang Perkawinan Dini. http://khazanah.republika.co.id/berita/dunia-islam/fatwa/16/07/14/oaampg313begini-islam-memandang-perkawinan-dini. Diakses Tanggal 14 April 2018.

Streubert \& Carpenter, S. 2011. Qualitative Research in Nursing: Advancing. Humanistic Imperativ (5 th Ed).

WHO. 2014. World Health Statistics 2014. Geneva, Switzerland: World Health Organization. 